\title{
THE EFFECTS OF LEARNING FROM WORD PAIRS ON WORD KNOWLEDGE
}

\author{
Sarimah Shamsudin \\ Language Academy \\ Universiti Teknologi Malaysia \\ KL Campus, Kuala Lumpur, Malaysia \\ and \\ Nur Afiqah Ab Rahman \\ Sekolah Kebangsaan Pendidikan Khas Johor Bahru \\ (Special Education Primary School) \\ Johor Bahru, Malaysia
}

\begin{abstract}
Vocabulary plays an essential role in language learning. The lack of vocabulary might cause incompetency to language users. It is therefore very important for language instructors to find suitable ways of teaching vocabulary since learning vocabulary consists of learning various aspects of word knowledge. These aspects include orthography, meaning and form, collocation, association and grammatical functions. There are various methods that could be used in gaining aspects of word knowledge. The purpose of this study is to investigate to what extent are aspects of word knowledge gained by learning from word pairs. 120 secondary school students were divided into four groups of thirty students. The first group was given a set of Malay Translation, the second, English Translation, the third, Malay Definition and the fourth, English Definition word pair to learn followed by word knowledge tests. The results show that all word pairs promote large gains in learning aspects of word knowledge. The scores between the groups were also compared and it was found that the mean score of the Malay Definition word pair group is the highest, followed by the Malay Translation word pair group, the English Translation word pair group, and English Definition word pair group.
\end{abstract}

Keywords: vocabulary teaching, word knowledge, word pairs

\section{INTRODUCTION}

Reading is one of the means for students to be successful. However, reading needs considerable amount of vocabulary, knowledge and skill. "This knowledge includes recognising the letters and words of the language, having a large vocabulary and substantial grammatical and textual knowledge, being able to bring knowledge of the world to the reading task, and developing a degree of fluency with the reading skill" (Nation, 2005:10). Everything begins with a good grasp of language which definitely requires learners to understand what is said or written in English. Only then learners will be able to produce the language in spoken and written form. Thus, it can be said that vocabulary is an essential element in reading and language learning.

Teachers often encourage their students to do a lot of reading. It does not matter what kind of materials the students are interested in. Most teachers believe that reading will make their students know more. On the other hand, most teachers forget that for the students to read, they first need to have sufficient vocabulary. "How can they learn enough words to learn vocabulary through extensive reading when they do not know enough words to read well?" (Coady, 1997:229). The text given to the students might also be too difficult for the students' level of proficiency. So, these students need the 
teacher's help to learn the words. By knowing a lot of words, learners will grasp the meaning of texts. Even if learners do not understand the full meaning, the words they know will help them in understanding the content of the text and later, add up to their word list. "Knowing a word is not an allor-nothing proposition" (Spencer \& Guillaume, 2009:2). The degree of knowing a word can range from being able to recognise the word to being able to define the word and also being able to use the word with other words.

The Input Hypothesis proposed by Krashen (1989) suggests that language learners acquire vocabulary and spelling most efficiently by receiving comprehensible input while reading. However, it is questionable how beginners of English will be able to understand what they read when they do not have enough vocabulary to do so. "No text comprehension is possible, either in one's native language or in a foreign language, without understanding the text's vocabulary" (Laufer, 1997:20).

The relationship between vocabulary knowledge and reading, however, is a two-way relationship. It can be the effect of vocabulary knowledge on reading or the effect of reading on vocabulary knowledge (Hu \& Nation, 2000). This relationship occurs at different times of learning. At the early stages of learning how to read, learners' vocabulary knowledge will support them in reading. Learning is fundamentally dependent on vocabulary knowledge (Baker, Simmons \& Kame'enui, 1997). Later on, reading will help them expand their vocabulary knowledge. This relationship shows that vocabulary knowledge and reading are two important factors in language learning.

One may argue that learners do not read much because they cannot understand the words used or vice versa, learners cannot understand the words simply because they do not read much. This problem is best defined by Nuttall (1982) in which she presents two circles that represent two types of readers. One is the Vicious Circle and the other is the Virtuous Circle. In the Vicious Circle, learners who do not understand what they read will read slowly, which lead them not to enjoy reading and that makes them reluctant to read much and consequently, they will not be able to understand the text. The cyclical process will continue unless the learners are able to escape from the Vicious Circle.

To break the Vicious Circle and enter the Virtuous Circle, learners need to have sufficient vocabulary. The most significant handicap for second language (L2) readers is not due to lack of reading strategies but insufficient vocabulary in English (Haynes \& Baker, 1993). In the Virtuous Circle, learners who have sufficient vocabulary will understand better, read more, enjoy reading and therefore, read faster. The teachers must be aware of these cycles and know how to move their students, especially low proficiency learners, from the Vicious Circle to the Virtuous Circle. Low proficiency learners do not have sufficient vocabulary to assist them in reading (Lehr, Osborn \& Hiebert, 2004) and difficulties in reading might hinder them to read more which make them know less.

Other than facing problems in reading in L2, lack of vocabulary will also lead to lack of communication skills. For one to communicate efficiently, he has to be able to express himself and explain things clearly. Problem with communication would not happen if he has sufficient vocabulary to do so. McCarthy (1990) also states that it does not matter how well the student learns grammar or L2 are mastered, without words to express a wide range of meanings, L2 communication cannot happen in a meaningful way.

Based on the discussion above, it can be seen that it is vital for language learners to expand their vocabulary. Expanding vocabulary is all about knowing more words as well as knowing more about a word. There are many aspects involved in knowing a word. This is referred to as vocabulary knowledge or known as word knowledge. Learners' word knowledge is closely related to academic accomplishment and it helps in learning other subjects as well. Word knowledge consists of different 
aspects of knowing a word which are the spoken form, written form, word parts, form and meaning, concepts and referents, associations, grammatical functions, collocations and constraints on use (Nation, 2001).

There might be thousands of strategies that can be used to help L2 learners in gaining word knowledge. Word pairs are one of them. Many studies have shown that word pairs can be fast and efficient methods in acquiring L2 vocabulary (Waring, 1997, Webb, 2002, Webb, 2007). The studies, however, focused on tertiary level students. Thus, the present study is interested in investigating the use of word pairs in L2 vocabulary learning among secondary school students in the Malaysian context.

Since learning a word means knowing its word knowledge, this study aims at looking the extent aspects of word knowledge is gained through learning from word pairs. Hence, the research questions addressed in this study were:

1. To what extent are aspects of word knowledge gained through learning from Malay Translation word pairs?

2. To what extent are aspects of word knowledge gained through learning from English Translation word pairs?

3. To what extent are aspects of word knowledge gained through learning from Malay Definition word pairs?

4. To what extent are aspects of word knowledge gained through learning from English Definition word pairs?

\section{METHODOLOGY}

This study used quantitative methods to explore the degree various facets of word knowledge is gained in the course of learning via four forms of word pairs.

Participants

The participants of this study were 120 Malay students from a secondary school in Malaysia. Malay students were chosen as the test uses Malay language in the word pair tasks. Secondary school students were chosen as most of the previous studies only looked at the performance of tertiary level students (see Stoddard, 1929, Griffin \& Harley, 1996, Waring, 1997, Webb, 2002, Webb, 2005 \& Webb 2007). There were three classes which ranged from intermediate to low proficiency students that were selected as the participants of the study. For each class, the researcher randomly assigned them to four different word pairs: Malay Translation, English Translation, Malay Definition and English Definition.

Research Instruments

There are three research instruments in the study. The first instrument is the Vocabulary Levels Test. This test was given to measure the respondents' vocabulary size. The test is taken from Nation (1993). The second instrument consists of four sets of word pairs, Malay Translation, English Translation, Malay Definition and English Definition. These word pairs were adapted from Webb (2002). The third instrument consists of the word knowledge tests which measure five aspects of word knowledge, receptively and productively. The word knowledge tests are adapted from Webb (2002).

Vocabulary Levels Test 
The Vocabulary Levels Test is a test developed by Nation (1983) that is used to measure the high-frequency words that have been learned, and the progress of the learner in the learning of lowfrequency vocabulary (Nation, 2001). In other words, this test is used to measure the breadth and not the depth of vocabulary. It is useful for teachers as a basis in planning vocabulary lesson and directing learners to the appropriate vocabulary (Nation, 1990). Furthermore, it measures vocabulary size at different word levels: 1000, 2 000, 3000,5000 and 10000 word level.

The present study used the Vocabulary Levels Test at 1000 word level as a minimum measurement of the students' vocabulary size. Two tests were given, Test A and Test B to eliminate the possibility of guessing. These two tests contain 40 items each and each test tests the same word in the same order.

\section{Word Pairs}

There are four sets of word pairs used in the study; Malay Translation (MT) word pairs (see Appendix A), English Translation (ET) word pairs (see Appendix B), Malay Definition (MD) word pairs (see Appendix C), and English Definition (ED) word pairs (see Appendix D). For each set of word pairs, the target words consist of six nouns and four verbs as both are the most common parts of speech found in natural text and the use of 6:4 ratios represents the proportional frequency of occurrence for both parts of speech (Kucera \& Francis, 1967). In testing vocabulary, it is almost impossible to find words that all the participants do not know as they have different background knowledge. Therefore, this study replaced the target words with nonsense words to eliminate the possibility of participants knowing the target words. Not only that, the use of nonsense words also eliminates the need for a pretest to measure participants' prior knowledge (Webb, 2005).

Ten nonsense words were selected from Webb's (2005) study as target words for the word pairs. They were then piloted with a group of 30 students. After the pilot study, the number of words for each set was reduced to eight due to time constraint as the study can only be conducted during English lessons within school hours. Students who had to learn MD and ED word pairs had to spend more time learning ten sentences rather than just ten words.

\section{Word Knowledge Tests}

The word knowledge tests are adapted from Webb (2002). There are ten tests measuring receptive and productive knowledge of orthography, association, collocation, grammatical functions, and meaning and form. Each test requires different marking criteria.

After learning the word pairs, the students had to answer ten tests which measure knowledge of orthography, grammatical functions, collocation, association, and meaning and form. The tests were carefully sequenced to avoid the risk of earlier tests affecting answers to later tests. Even though the tests were adapted from Webb's (2002) study, the researcher found that Nation (2001) also suggested the same test format for testing each of the word knowledge. The format of the test is shown in Table 1.

Table 1

Word Knowledge Tests (Adapted from Webb, 2002)

\begin{tabular}{|l|l|l|}
\hline Test & Test Type & Title of the Test \\
\hline
\end{tabular}




\begin{tabular}{|l|l|l|}
\hline Test 1 & Spelling & Productive Knowledge of Orthography Test \\
\hline Test 2 & Multiple-choice & Receptive Knowledge of Orthography Test \\
\hline Test 3 & Translation & Productive Recall of Meaning and Form Test \\
\hline Test 4 & Sentence construction & Productive Knowledge of Grammatical Functions Test \\
\hline Test 5 & $\begin{array}{l}\text { Write a syntagmatic } \\
\text { associate }\end{array}$ & Productive Knowledge of Collocation Test \\
\hline Test 6 & $\begin{array}{l}\text { Write a paradigmatic } \\
\text { associate }\end{array}$ & Productive Knowledge of Association Test \\
\hline Test 7 & Multiple-choice & Receptive Knowledge of Grammatical Functions Test \\
\hline Test 8 & Multiple-choice & Receptive Knowledge of Collocation Test \\
\hline Test 9 & Multiple-choice & Receptive Knowledge of Association Test \\
\hline Test 10 & Translation & Receptive Recognition of Meaning and Form Test \\
\hline
\end{tabular}

The first test is the Productive Knowledge of Orthography Test. The purpose of this test is to look at the students' ability in spelling the target words based on the researcher's pronunciation. Previously, during the learning of word pairs, the researcher pronounced the target words to familiarise the students with the pronunciation. The students were told that they have to listen to the words pronounced by the researcher. The researcher pronounced the words twice and the students had 10 seconds to write the word correctly. Since the focus of Test 1 is to measure orthography, any spelling mistake is marked as incorrect.

The second test is the Receptive Knowledge of Orthography Test which tests whether the students are able to recognise the spelling of the target words. This test requires the students to circle the correct spelling of the target words which appear with three distracters. The distracters are created to resemble the target words both phonetically and orthographically.
a) masko
b) mesco
c) masco
d) mesko

Generally, all productive tests should be completed before receptive tests to avoid any learning effects. However, it was very unlikely that the receptive knowledge of orthography would contribute to learning effects in this study. Webb (2005) stated two reasons for this 1) the target words were used as cues on the remaining tests, 2) the determining factor on the other test measuring productive knowledge of meaning and form was whether the participants could link the $L 2$ form with its meaning rather than spelling the L2 form correctly.

The productive recall of meaning and form is measured by asking the students to write the first language (L1) translation of the target word. The aim of this test (Test 3 ) is to determine whether the students could link the target words with their L1 meaning. Spelling is not the aim of this test as the researcher is more interested to see whether the respondents have the ability to write the L1 equivalent of the target words.

The aim of Productive Knowledge of Grammatical Functions Test (Test 4) is to see whether the students could use the target words correctly based on their functions. They were asked to write a sentence for each target word. For instance, the use of masco or "train" in the sentence "She went back to her village by masco" would have been marked as correct while in the sentence "He mascoed loudly" would be incorrect.

In the Productive Knowledge of Collocation Test which is Test 5 , the students were asked to write words they often see together with the target words. The purpose of this test is to find out whether the students could link the target words with everyday usage. For example, the word make-up and mirror are marked as correct for the target word hodet (face) as these words are often used together with the word face. 
The Productive Knowledge of Association Test (Test 6) requires the students to write words that are associated with the target words. Synonyms, antonyms, coordinates, subordinates, superordinates are scored as correct. The focus of this test is for the students to write words that are related in terms of meaning. For example, the words summer, temperature will be accepted for the target word 'hot'.

The Receptive Knowledge of Grammatical Functions Test which is Test 7, measures receptive knowledge of grammatical functions by using multiple-choice test. Students are given three sentences for each target word and are asked to choose one sentence that has the correct form of the target words. For instance, a noun should not have a tense. This test requires the respondents to have the knowledge of parts of speech. In the example below, a) would be the correct use of the word ancon (family).

a) They are my ancon.

b) They are anconed.

c) They are very ancon.

Test 8 which is the Receptive Knowledge of Collocation Test requires the students to choose a word that often appears or is seen together with the target word. Its purpose is to find out whether the students can choose the correct word for everyday usage. For example, the word hodet (face) is often seen with mirror.
hodet
a) town
b) mirror
c) leave
d) serve

In measuring the receptive knowledge of association, multiple-choice items are given. For this test (Test 9), the respondents have to choose words that are associated with the target words. For example, the word masco (train) is associated with transportation.
masco
a) work
b) conversation
c) shopping
d) transportation

The Receptive Recognition of Meaning And Form Test requires the respondents to translate the target words to their L1 (Test 10). Since this test is a receptive test, an argument can be made that this test involves both receptive and productive processes (Waring, 1997). However, Webb (2005) argued that because the respondents have learned the answers in the treatments, a recognition test would have been very easy. Nation (2001) also suggested L1 translation as the test item for receptive knowledge of meaning and form. Thus, a receptive translation test is better as it was more demanding and requires participants to recall rather than recognise meanings. For example, students are required to write the Malay translation of visit which is lawat beside the nonsense word sagod.

Procedure

The researcher conducted the Vocabulary Levels Tests at 1000 word levels to measure the respondents' vocabulary size. Two tests were given, Test A and Test B. One mark is given only if the students answer the question correctly in both tests. For example, in testing whether the student understands the use of the word 'little', he has to answer the first question in Test A and Test B. Marks will be given only if they answer both questions correctly. To calculate the respondents' vocabulary size, their marks will be multiplied by 2.5 (Nation, 1993).

Next, the students were randomly divided into four groups. Group 1 learned Malay Translation word pairs, Group 2 learned English Translation word pairs, Group 3 learned Malay Definition word pairs and Group 4 learned English Definition word pairs. 
The students were allowed to take as much time as they needed to study the word pairs given. At the beginning of the learning time, the researcher pronounced the target words to familiarise the students with the pronunciation. The students were told that they have to answer ten tests afterwards. After completing the treatments, the students were briefed on the tests. The students were asked to complete the test in order. Once they had finished Test 1, they had to submit the test first and then continue with Test 2 and so on. There was no time limit in answering the test. In other words, the students could submit each test without waiting for other students to complete. The quantitative data gathered from this study were tabulated using descriptive statistics.

\section{RESULTS}

Analysis of Vocabulary Levels Test

Table 2 shows the results of the Vocabulary Levels Tests at 1000 word level for all the students. The results reflect the vocabulary level of the students. From a total of 120 students who sat for the test, 67.5 percent or 81 students scored 60 percent or higher with 19 students or 15.8 percent performed exceptionally well and attained 80 percent or higher which indicates that they know most of the words tested. Meanwhile, 34 students or 28.4 percent know between 40 to 59 percent of the word tested. On the other hand, five students or 4.1 percent did very badly, getting score lower than 40 percent.

Based on the analysis, it can be said that approximately 86 percent of the students did well in the test and scored at least 50 percent. To avoid guessing, there were two vocabulary tests which tested the same item but different sentences were given. A mark is given only when both items testing a word are correct. During the marking, the researcher realised that a number of the students attained only one item correct when they should get both items correct to get a mark. This happened probably because they did not really understand the meaning of the word tested or they just guessed the answer.

Table 2

Vocabulary Levels Tests Score

\begin{tabular}{|c|c|c|}
\hline $\begin{array}{c}\text { Vocabulary Levels } \\
\text { Test Score }\end{array}$ & Number of Students & Percentage (\%) \\
\hline $80-100$ & 19 & 15.8 \\
\hline $60-79$ & 62 & 51.7 \\
\hline $50-59$ & 23 & 19.2 \\
\hline $40-49$ & 11 & 9.2 \\
\hline $0-39$ & 5 & 4.1 \\
\hline Total & 120 & 100 \\
\hline
\end{tabular}

Analysis of Vocabulary Levels Tests versus Word Knowledge Tests

Table 3 shows the mean score and the percentage of word knowledge tests based on the Vocabulary Levels Tests score. As can be seen in Table 3, the word knowledge tests score increases as the Vocabulary Levels Tests score increases. Overall, students who scored 80 to 100 percent in the Vocabulary Levels Tests did well in answering the word knowledge tests than those who scored below 80 percent. This shows that the students' vocabulary size plays an important role in answering any vocabulary-related tests. The results also prove that vocabulary size does matter in learning language. 
Table 3

Vocabulary Levels Tests versus Word Knowledge Tests Score

\begin{tabular}{|l|c|c|c|c|c|c|c|c|c|c|c|}
\hline $\begin{array}{c}\text { Vocabulary } \\
\text { Levels } \\
\text { Test Score }\end{array}$ & $\begin{array}{c}\text { Test } \\
\mathbf{1}\end{array}$ & $\begin{array}{c}\text { Test } \\
\mathbf{2}\end{array}$ & $\begin{array}{c}\text { Test } \\
\mathbf{3}\end{array}$ & $\begin{array}{c}\text { Test } \\
\mathbf{4}\end{array}$ & $\begin{array}{c}\text { Test } \\
\mathbf{5}\end{array}$ & $\begin{array}{c}\text { Test } \\
\mathbf{6}\end{array}$ & $\begin{array}{c}\text { Test } \\
\mathbf{7}\end{array}$ & $\begin{array}{c}\text { Test } \\
\mathbf{8}\end{array}$ & $\begin{array}{c}\text { Test } \\
\mathbf{9}\end{array}$ & $\begin{array}{c}\text { Test } \\
\mathbf{1 0}\end{array}$ & All Tests \\
\hline $80-100$ & 7.60 & 7.80 & 8.00 & 7.90 & 7.40 & 2.80 & 7.70 & 7.90 & 7.80 & 8.00 & $7.44(93 \%)$ \\
\hline $60-79$ & 6.66 & 7.36 & 6.98 & 6.16 & 5.75 & 3.02 & 6.89 & 7.20 & 7.32 & 7.93 & $6.69(83.7 \%)$ \\
\hline $50-59$ & 6.36 & 7.45 & 6.23 & 6.00 & 5.59 & 3.09 & 6.36 & 7.05 & 6.77 & 7.55 & $6.27(78.4 \%)$ \\
\hline $40-49$ & 5.56 & 7.00 & 5.00 & 4.56 & 4.67 & 2.33 & 4.33 & 5.56 & 5.78 & 6.89 & $5.50(68.8 \%)$ \\
\hline $0-39$ & 6.00 & 7.20 & 3.80 & 3.80 & 4.60 & 1.80 & 5.60 & 6.80 & 6.60 & 7.20 & $5.34(66.8 \%)$ \\
\hline All Tests & 6.54 & 7.39 & 6.53 & 6.02 & 5.72 & 2.88 & 6.52 & 7.06 & 7.04 & 7.70 & $6.56(82 \%)$ \\
\hline
\end{tabular}

Note. Maximum score $=8$.

Analysis of Word Knowledge Tests

The mean scores and mean percentage of the word knowledge tests are shown in Table 4. Table 4 shows that all four sets of word pairs promote gains in all aspects of word knowledge. The gains, however, differ from one word pair to another. It can be seen that the group who had MD word pairs obtained the highest mean scores in six out of ten tests. This occurred most probably because the students are Malay native speakers. Hence, they are used to things explained in Malay and would therefore hardly experience any problems understanding the word pairs given. Overall, the MD group attained the highest mean score for all ten tests, 7.23 or 90.4 percent. The second highest mean score was attained by the MT group with the mean score, 6.79 or 84.9 percent. This is followed by the ET and ED group with the mean scores, 6.65 or 83.1 percent and 5.58 or 69.8 percent, respectively. Since the results revealed that all four sets of word pairs promote gains in the tested word knowledge, it can be said that the word pairs can be used as one of the teaching techniques in teaching vocabulary. Thus, the score for each test can be used as a guide in deciding which type of word pairs is suitable to teach a certain aspect of vocabulary.

Table 4

Word Knowledge Tests Score of Word Pair Groups

\begin{tabular}{|c|c|c|c|c|c|c|c|c|c|c|c|}
\hline $\begin{array}{c}\text { Word } \\
\text { Pair } \\
\text { Group }\end{array}$ & $\begin{array}{c}\text { Test } \\
1\end{array}$ & $\begin{array}{c}\text { Test } \\
\mathbf{2}\end{array}$ & $\begin{array}{c}\text { Test } \\
3\end{array}$ & $\begin{array}{l}\text { Test } \\
\mathbf{4}\end{array}$ & $\begin{array}{c}\text { Test } \\
5\end{array}$ & $\begin{array}{c}\text { Test } \\
6\end{array}$ & $\begin{array}{c}\text { Test } \\
7\end{array}$ & $\begin{array}{c}\text { Test } \\
8\end{array}$ & $\begin{array}{l}\text { Test } \\
9\end{array}$ & $\begin{array}{c}\text { Test } \\
10\end{array}$ & $\begin{array}{l}\text { All } \\
\text { Tests }\end{array}$ \\
\hline $\begin{array}{c}\mathrm{MT} \\
\mathrm{n}=30\end{array}$ & $\begin{array}{c}7.23 \\
(90.4 \%)\end{array}$ & $\begin{array}{c}7.57 \\
(94.6 \%)\end{array}$ & $\begin{array}{c}7.37 \\
(92.1 \%)\end{array}$ & $\begin{array}{c}7.10 \\
(88.8 \%)\end{array}$ & $\begin{array}{c}6.43 \\
(80.4 \%)\end{array}$ & $\begin{array}{c}2.77 \\
(34.6 \%)\end{array}$ & $\begin{array}{c}6.83 \\
(85.4 \%)\end{array}$ & $\begin{array}{c}7.47 \\
(93.4 \%)\end{array}$ & $\begin{array}{c}7.23 \\
(90.4 \%)\end{array}$ & $\begin{array}{c}7.90 \\
(98.8 \%)\end{array}$ & $\begin{array}{c}6.79 \\
(84.9 \%)\end{array}$ \\
\hline $\begin{array}{c}E T \\
n=30\end{array}$ & $\begin{array}{c}6.43 \\
(80.4 \%)\end{array}$ & $\begin{array}{c}7.30 \\
(91.3 \%)\end{array}$ & $\begin{array}{c}7.23 \\
(90.4 \%)\end{array}$ & $\begin{array}{c}6.83 \\
(85.4 \%)\end{array}$ & $\begin{array}{c}5.93 \\
(74.1 \%)\end{array}$ & $\begin{array}{c}3.37 \\
(42.1 \%)\end{array}$ & $\begin{array}{c}6.83 \\
(85.4 \%)\end{array}$ & $\begin{array}{c}7.37 \\
(92.1 \%)\end{array}$ & $\begin{array}{c}7.40 \\
(92.5 \%)\end{array}$ & $\begin{array}{c}7.80 \\
(97.5 \%)\end{array}$ & $\begin{array}{c}6.65 \\
(83.1 \%)\end{array}$ \\
\hline $\begin{array}{c}M D \\
n=30\end{array}$ & $\begin{array}{c}7.13 \\
(89.1 \%)\end{array}$ & $\begin{array}{c}7.67 \\
(95.9 \%)\end{array}$ & $\begin{array}{c}7.73 \\
(96.6 \%)\end{array}$ & $\begin{array}{c}6.60 \\
(82.5 \%)\end{array}$ & $\begin{array}{c}5.93 \\
(74.1 \%)\end{array}$ & $\begin{array}{c}7.23 \\
(90.4 \%)\end{array}$ & $\begin{array}{c}6.90 \\
(86.3 \%)\end{array}$ & $\begin{array}{c}7.33 \\
(91.6 \%)\end{array}$ & $\begin{array}{c}7.80 \\
(97.5 \%)\end{array}$ & $\begin{array}{c}8.00 \\
(100 \%)\end{array}$ & $\begin{array}{c}7.23 \\
(90.4 \%)\end{array}$ \\
\hline ED & 5.97 & 7.30 & 5.00 & 4.13 & 4.80 & 2.50 & 5.90 & 6.33 & 6.50 & 7.40 & 5.58 \\
\hline
\end{tabular}


Note. Maximum score=8. Key. MT=Malay Translation, ET=English Translation, ED=English Definition, ED=English Definition.

\section{DISCUSSION}

In this study, the mean scores for all the receptive tests (Test 2, Test 8, Test 9 and Test 10), except one (Test 7) are higher than the productive tests (Test 1, Test 3, Test 4, Test 5 and Test 6 ) through learning from word pairs. Receptive learning tasks seem to promote substantial gains in receptive knowledge as opposed to productive tests which led to slightly lower gains in productive knowledge. This occurred probably because it is easier to gain receptive knowledge than productive knowledge (Stoddard, 1927; Waring, 1997). Thus, to be able to use words receptively, learners may need to learn them receptively, and to use words productively, they may need to learn the words productively.

All aspects of word knowledge are gained through learning from MT word pairs. The largest gain is receptive recognition of meaning and form (Test 10), with the mean score, 7.90 or 98.9 percent and the lowest gain is productive knowledge of association (Test 6), with the mean score, 2.77 or 34.6 percent. Overall, the students who learned from MT word pairs scored above 80 percent in all tests except in the productive knowledge of association test. This shows that by learning from L1 translation, learners will be able to gain partial knowledge of most of the aspects of word knowledge tested. On the other hand, MT word pairs might not be an effective method in teaching association productively. One of the possible reasons might be because the students were required to learn Malay translation but were asked to answer in English. These findings contrast with the findings from Webb's (2002) in which he compares L1 translation word pair (TWP) to L1 meanings and context word pair among 84 EFL students in Kyushu University. Each set of word pairs contains 20 target words with their meaning or translation. The results of his research showed that the TWP group's highest score is 73.5 percent in the receptive knowledge of orthography test and their lowest score is 40.6 percent in the productive knowledge of syntax test.

There are gains in all aspects of word knowledge tested through learning from ET word pairs. However, the gains differ from one to another. Similar to the MT word pairs group, the highest gain is receptive recognition of meaning and form (Test 10), with the mean score, 7.80 or 97.5 percent. This result is also similar to the study done by Webb (2002) in which he compared learning from repetitions from learning from English synonyms word pairs. In his study, the word pairs group scored the highest score in receptive recognition of meaning and form with 95.7 percent. Meanwhile, the lowest gain of ET word pairs in the present study is productive knowledge of association (Test 6), with the mean score, 3.37 or 42.1 percent. This finding differs from Webb's (2002) finding in which his word pairs group lowest score was in productive knowledge of syntax test with 47.4 percent. Even though Webb's 
(2002) study showed differences from the present study in the gains of each aspect, his findings, similarly, suggest that word pairs promote large gains in learning word knowledge.

The MD word pairs promote large gains in all aspects of word knowledge. The largest gain is receptive recognition of meaning and form (Test 10), with the mean score, 8.00 or 100 percent and the lowest gain is productive knowledge of collocation (Test 5), with the mean score, 5.93 or 74.1 percent. The overall results are similar to Webb's (2002) findings in one of his studies where he compared learning from L1 translations to L1 meanings plus context word pairs. Webb (2002) found that there are large gains in all aspects of word knowledge. Even though the percentage is different from the current study, Webb's (2002) study supports the findings of the present study by stating that word pairs are effective methods in vocabulary acquisition. As can be seen from Table 4, the percentage of each test varies from one to another. This should not be a factor for not using word pairs to teach and learn vocabulary. Instead, word pairs could be used as a primary or an additional method alongside other methods.

There are gains in all aspects of word knowledge through learning from ED word pairs. The largest gain is receptive recognition of meaning and form (Test 10), with the mean score, 7.40 or 92.5 percent, and the lowest gain is productive knowledge of association (Test 6), with the mean score, 2.50 or 31.3 percent. There are several facts that can be gleaned from the findings. It is shown that learning from ED word pairs has been proven as the most difficult word pairs in the present study. Thus, in reality, teachers who explain English words by giving lengthy explanation in English might just make their students even more confused. In the present study, although the students were given context for the target words, their overall score is still the lowest score among other word pairs.

Based on the analysis discussed, it is proven that learning from word pairs, indeed, promotes gains in at least five aspects of word knowledge. The gains, however, vary from one set of word pairs to another. As can be seen in Table 4, the overall mean scores ranged from 69 to 90 percent. The MD group scores the highest mean percentage, 90.4 percent among the four groups which indicates that the use of $L 1$ helps in gaining partial knowledge of $L 2$ vocabulary (Webb, 2007). The same goes with the MT group, the second highest group with the mean percentage of 84.9 percent, showing that the use of Malay, regardless of the types of word pairs, plays an important role in learning L2 vocabulary. Surprisingly, the use of English as the medium in learning English vocabulary, even though there are gains, they are lower than the Malay groups. The ET group scores 83.1 percent while the ED group scores the lowest mean percentage, 69.8 percent. This happens most probably because the students are unable to fully understand the translations and definitions given in English, which means they had high learning burden, and this led to problems in answering the tests. In contrast, the MD and MT groups had lower learning burden, making them learn faster which supports Nation's theory of learning burden (Nation, 1990, 2001). As students who had Malay word pairs scored higher than the English word pair groups, it can be said that the use of L1 can actually help students in learning L2. In the Malaysian context, it may be concluded that using L1, for example using Tamil for the Indians, Mandarin for the Chinese and Malay language for the Malays, has more potential in helping language learners learn the English language and gain knowledge of $L 2$ vocabulary.

The present study also confirms that the students are able to use L1 knowledge in the MT and MD word pairs to gain substantial knowledge of an unknown L2 word (Webb, 2002). The low gains of collocation and association knowledge might be due to the students' lack of vocabulary which limits their ability in producing the correct collocation and association for the tested words. Other than that, the productive tests of collocation and association require the students to think of words that are often used and appear together with the target words. The students were needed to critically think and use 
their prior knowledge to get the correct answer. Compared to other tests, these two tests had the lowest gains which showed that the students are probably incapable of applying their prior knowledge and thinking skills in answering the tests. They may have simply relied on their memorising ability. In other words, this creates an assumption that majority of Malaysian students learn by memorisation, not by understanding and applying the knowledge they have gained.

\section{CONCLUSION}

It can be summarised that the students were able to answer all receptive tests successfully. Their mean scores, 80 percent and above, showed that learning from word pairs helps them in gaining receptive knowledge of the tested aspects of word knowledge. On the contrary, the low mean scores gained in three out of five productive tests, below 80 percent, show that word pairs might not be enough if it is used solely in teaching productive knowledge of vocabulary. Overall, the results show that all word pairs promote large gains in learning aspects of word knowledge. The scores between the groups were also compared and it was found that the MD word pairs group scored the highest mean percentage, 90 percent, followed by the MT word pairs group, 85 percent, the ET word pairs group, 83 percent, and ED word pairs group, 70 percent.

In analysing the data of this study, the results seem to indicate that the students may have relied on their memorising ability to answer the tests. Based on Bloom's Taxonomy of cognitive domain (1956), memorising is included under the knowledge category which is the lowest cognitive skill in the taxonomy. In other words, based on the findings in which the mean scores for all the students were at least 80 percent in the receptive tests, it can be said that the students are only able to recall the meaning and definition given to them. Other than that, a small number of students are able to demonstrate their comprehension skills in which they understood the word pairs given and were able to demonstrate their understanding by rewriting meaning, translating and interpreting meaning from the definition given in word pairs. In addition, based on the low scores of Test 5 (Productive Knowledge of Collocation Test) and Test 6 (Productive Knowledge of Association Test), it can be concluded that most of the students failed to demonstrate the third cognitive skill in Bloom's Taxonomy which is application. Most of them are unable to apply what they have learned throughout their school years in the tests especially in giving words that often appear and are associated with the target words. In brief, since a majority of the students showed that they only have knowledge and comprehension skills, it is very important for teachers in Malaysia to start thinking of teaching techniques to enable the students to acquire higher levels of cognitive skills which include application, analysis, synthesis and evaluation.

Based on the findings of the study, there are several conclusions that can be drawn. Firstly, learning from word pairs has the potential to help students gain at least five aspects of word knowledge which are orthography, meaning and form, grammatical functions, collocation and association. Secondly, learning from L1 definition word pairs seems to be the most effective method of acquiring vocabulary followed by L1 translation word pairs in the context of this study. Finally $L 2$ definition word pairs and L2 translation word pairs seems to offer the least opportunity for vocabulary acquisition and should be used with caution by language instructors to avoid confusion.

\section{REFERENCES}

Baker, S. K., Simmons, E. J. and Kame'enui, E. J. (1997). Vocabulary acquisition: Research bases. In D. C. Simmons and E. J. Kame'enui, (Eds.), What Reading Research Tells Us about Children with Diverse Learning Needs: Bases and Basics, pp. 183-218. Mahwah, NJ: Erlbaum. 
Coady, J. (1997). L2 vocabulary acquisition through extensive reading. In J. Coady, and T. Huckin, (Eds.) Second-Language Vocabulary Acquisition: A Rationale for Pedagogy, pp. 225-237. Cambridge: Cambridge University Press.

Bloom B. S. (1956). Taxonomy of Educational Objectives, Handbook I: The Cognitive Domain. New York: David McKay Co Inc.

Griffin, G. F. and Harley, T. A. (1996). List learning of second language vocabulary. Applied Psycholinguistics.17(4), pp. 443-460.

Haynes, M. and Baker, I. (1993). American and Chinese readers learning from lexical familiarization in English texts. In T. Huckin, M. Haynes, and J. Coady, (Eds.), Second Language Reading and Vocabulary Acquisition, pp. 130-152. Norwood, NJ: Ablex.

Lehr, F., Osborn, J., and Hiebert, E. H., (2004). A Focus on Vocabulary. Pacific Resources for Education And Learning. Retrieved December 8, 2009 from http://vineproject.ucsc.edu/resources/A\%20Focus\%20on\%20Vocabulary\%20PREL.pdf

Hu, M. and Nation, I. S. P. (2000) Unknown vocabulary density and reading comprehension. a Foreign Language. Vol. 13(1), pp. 403-430.

Krashen, S. (1989). Language Acquisition and Language Education. New York: Prentice Hall International.

Kucera, H and Francis, W. N. (1967). Computational Analysis of Present-Day American English. Providence, Rl: Brown University Press.

Laufer, B. (1997). The lexical plight in second language reading: Words you don't know, words you think you know, and words you can't guess. In J. Coady and T. Huckin, (Eds) Second Language Vocabulary Acquisition, pp. 20-34. Cambridge: Cambridge University Press.

McCarthy, M. (1990). Vocabulary. Oxford: Oxford University Press.

Nation, I. S. P. (1983). Testing and teaching vocabulary. Guidelines. 5(1), pp. 12-25.

Nation, I. S. P. (1990). Teaching and Learning Vocabulary. Massachusetts: Heinle \& Heinle Publishers.

Nation, I. S. P. (1993). Measuring readiness for simplified materials: A test of the first 1,000 words of English. In M. L. Tickoo, (Ed.), Simplification: Theory And Application, pp.193-203. RELC Anthology Series, 31.

Nation, I. S. P. (2001). Learning Vocabulary in Another Language. Cambridge: Cambridge University Press.

Nation, I. S. P. (2005). Vocabulary learning through extensive reading. In G. Poedjosoedarmo,. (Ed.), Innovative Approaches to Reading and Writing, pp. 10-21. RELC Anthology Series 46. RELC, Singapore.

Nuttall, C. (1982). Teaching Reading Skills in a Foreign Language. London: Heinemann. 
Spencer, B.H. and Guillaume, A. M. (2009). 35 Strategies for Developing Content Area Vocabulary. Boston: Pearson.

Stoddard, G. D. (1929). An experiment in verbal learning. Journal of Educational Psychology. 20(6), pp. 452-457.

Waring, R. (1997) A study of receptive and productive learning from word cards. Studies in Foreign Languages and Literature (Notre Dame Seishin University, Okayama). 21(1), pp. 94-114.

Webb, S. (2002) .Investigating the Effects of Learning Tasks on Vocabulary Knowledge. Unpublished Ph.D Thesis. Victoria University of Wellington.

Webb, S. (2005). Receptive and productive vocabulary learning: The effects of reading and writing on word knowledge. Studies in Second Language Acquisition. 27(1), pp. 33-52.

Webb, S. (2007). Learning word pairs and glossed sentences: The effects of a single context on vocabulary knowledge. Language Teaching Research. 11 (1), 63-81. 
APPENDIX A

\section{Malay Translation Word Pairs}

Learn the words given below and their meaning.

\begin{tabular}{|c|c|c|c|}
\hline Words & & & Malay Translation \\
\hline masco & /ma :skp / & - & keretapi \\
\hline pacon & $/ p_{\varepsilon} \mathrm{kp} \mathrm{n} /$ & - & pakai \\
\hline sagod & /sa go d/ & - & lawat \\
\hline denent & $/ d_{\varepsilon} n_{\varepsilon} t /$ & - & ingat \\
\hline dangy & /d $\varepsilon$ ngi:/ & - & lorong \\
\hline cader & /keidə / & - & makanan tengah hari \\
\hline hodet & /ho :det/ & - & muka \\
\hline tasper & /te spə / & - & petang \\
\hline
\end{tabular}




\section{APPENDIX B}

\section{English Translation Word Pairs}

Learn the words given below and their meaning.

\begin{tabular}{|c|c|c|c|}
\hline Words & & & English Translation \\
\hline masco & /ma :skp / & - & train \\
\hline pacon & $/ p_{\varepsilon} \mathrm{kp} \mathrm{n} /$ & - & wear \\
\hline sagod & /sa go d/ & - & visit \\
\hline denent & $/ \mathrm{d}_{\varepsilon} \mathrm{n}_{\varepsilon} \mathrm{t} /$ & - & remember \\
\hline dangy & /de ngi:/ & - & street \\
\hline cader & /keidə / & - & lunch \\
\hline hodet & /ho :det/ & - & face \\
\hline tasper & /te spə / & - & evening \\
\hline
\end{tabular}




\section{APPENDIX C}

\section{Malay Definition Word Pairs}

Learn the words given below and their meaning.

Words

masco

pacon

sagod

denent

dangy

cader

hodet

tasper

\section{Malay Definition}

Ima :skp / - Kenderaan yang beroda yang dijalankan oleh enjin di atas landasan rel.

$/ p_{\varepsilon} \mathrm{kp} \mathrm{n} / \quad$ - Mengenakan seluar, baju, kasut dan sebagainya.

/sa go d/ - Pergi melihat sesuatu tempat, mengunjung.

/d $\varepsilon n_{\varepsilon} t / \quad$ - Masih ada dalam fikiran, tidak lupa.

/d\& ngi:/ - Jalan kecil.

/keidə / - Makanan yang dimakan pada waktu tengah hari.

/ho :de t/ - Bahagian hadapan kepala dari dagu hingga ke atas dahi.

/tє spə / - Waktu selepas tengah hari hingga matahari terbenam. 


\section{APPENDIX D}

\section{English Definition Word Pairs}

Learn the words given below and their meaning.

Words

masco

pacon

sagod

denent

dangy

/de ngi:/ -

cader

hodet

tasper

\section{English Definition}

/ma :skp / -

A line of coaches or wagons coupled together and drawn by a railway locomotive.

$/ p \varepsilon \mathrm{kp} \mathrm{n} / \quad$ - To be dressed, to have clothes on your body.

/sa gr d/ - To go to see a place or a person for a short time.

$/ \mathrm{d} \varepsilon \mathrm{n}_{\varepsilon} \mathrm{t} / \quad$ - Not to forget something.

A road in a town or village with houses and other buildings along each side.

/keidə / - A meal eaten during the middle of the day.

/ho :de t/ - The front part of your head where your eyes, nose, mouth are.

It\& spə / - The latter part of the day, especially from late afternoon until nightfall. 